This is an accepted manuscript of an article published by Taylor \& Francis in Applied Economics Letters on 2019, available online: https://doi.org/10.1080/13504851.2018.1558335

\title{
Disentangling the Transmission Channel NPLs-Cost of Capital-Lending Supply
}

Gabriella Chiesa ${ }^{a *}$ and José Manuel Mansilla-Fernández ${ }^{\mathrm{b}}$

${ }^{a}$ Department of Economics, University of Bologna, Bologna, Italy; ${ }^{b}$ Business Administration Department, Public University of Navarre, Pamplona, Spain

Provide full correspondence details here including e-mail for the *corresponding author:

a Department of Economics, University of Bologna, Piazza Scaravilli 2, 40126 - Bologna, Italy. E-mail: gabriella.chiesa@unibo.it

Provide short biographical notes on all contributors here if the journal requires them. 


\section{Disentangling the Transmission Channel NPLs-Cost of Capital-Lending Supply}

This paper analyses the effects of non-performing loans (NPLs) on the cost of capital, and on lending and liquidity supply, for a sample of 225 Eurozone banks over the period 2002Q1-2016Q4. Our results demonstrate that NPLs increase the cost of capital, which reduces both lending supply and liquidity creation. This phenomenon is comparatively more significant for periphery county banks than for core country banks.

Keywords: cost of capital; credit supply; liquidity creation; leverage; NPLs

Subject classification codes: G11; G21; G32; H63

\section{Introduction}

In the aftermath of the 2008 financial crisis, the Eurozone banks experienced a growing path of non-performing loans (NPLs hereafter) fuelled by adverse macroeconomic conditions (Aiyar et al., 2015). The evolution of NPLs was comparatively sharper for banks operating in the so-called periphery countries than for those in core countries (Chiesa and MansillaFernández, 2018; ESRB, 2017).

At the bank level, insofar as large volumes of NPLs are accumulated in the balance sheet, investors might cast doubt on the viability of the bank's business model, future profitability and asset values, thus requiring relatively higher returns on equity investment as a compensation for undiversifiable risk. Secondly, according to the current banking regulation, equity serves as a buffer to absorb possible bank losses and avoid bankruptcy or, more generally, restructuring. The bank can control its default probability by limiting risk-taking, that is, by restricting lending and liquidity creation, and / or by issuing equity (Calomiris and Jaremski, 2016). The bank's choice will depend on the return that investors require to hold bank equity, i.e. the bank's cost of capital. 
This article contributes to the existing literature by analysing the following two-step transmission channel of NPLs' holdings. We investigate whether NPLs foster equity investors' required returns and hence the bank's cost of capital. Secondly, we analyse whether the cost of capital has a negative effect on lending volumes and liquidity creation, and whether these effects are exacerbated by the shortage of bank capital.

To perform our empirical analysis, we create a unique dataset by combining bank and market information from Bureau van Dijk's Bankscope and Thomson Reuters Datastream consisting of 5,160 (225 Eurozone listed banks) observations for the period 2002Q1-2016Q4. We calculate the NPLs ratio as the ratio of impaired loans to total loans, and the cost of capital by using the standard CAPM model. We use the instrumental variable (IV) estimator to analyse the two-step transmission channel. We contribute to the existing literature by showing that: (i) NPLs increase the bank's cost of capital, (ii) this effect leads to reductions in lending supply and liquidity creation, and even more so in the less capitalized banks. These results are robust to the standard endogeneity tests.

The remainder of the paper proceeds as follows. Section II provides the background for the theoretical and empirical literature. Section III describes the data. Section IV illustrates the methodology. Section V offers the main results, conclusions are drawn in Section VI.

\section{Literature review}

This article is related to the following two strands of literature. The first question raised in this research is whether banks which hold certain levels of NPLs could face increases in the cost of capital. So far, previous literature has focused on the determinants of NPLs, mainly due to bank undercapitalization (Caprio and Summers, 1993; Calomiris and Jaremski, 2016), moral hazard issues (Berger and DeYoung, 1997), and aggregate risk (Louzis, Vouldis, and Metaxas, 2012; Pinto and Picoto, 2018). Our paper is one of the first attempts at analysing the repercussions of NPL holdings on the cost of capital for banks. 
Regarding our second research question, i.e., the effects on lending and liquidity creation, the consensus is that banks with relatively high levels of NPL ratios lend less than others, ceteris paribus (Afonso, Kovener, and Schoarn, 2011; Balgova, Nies, and Plekhanov, 2016; Bending et al., 2014). ${ }^{1}$ The role of bank capital has been considered the cornerstone of the standard theory of banking regulation, since it determines the level of lending that the bank is allowed to supply (Berger and Bowman, 2009, 2013; Dagher et al., 2014; van der Heuvel, 2008). Accornero et al. (2017) show that bank lending is steered by demand factors instead of the volume of NPLs, even though reductions in the book value of capital (measured through the Asset Quality Review) adversely affect lending. This suggests that a more detailed analysis of the NPLs' transmission mechanism is needed.

\section{Sample banks and data}

The construction of the dataset proceeds as follows:

i. Bank information. We collect quarterly consolidated information from Bureau van Dijk's Bankscope for a sample of 225 Eurozone listed banks for the period 200Q12016Q4. ${ }^{2}$

ii. Market information. We consider the Eurozone market portfolio as our laboratory. We retrieve monthly information about bank equity prices, EURO STOXX index to

${ }^{1}$ Levels of NPLs above a threshold might incentivize banks to assume higher risk in the future in a 'gamble to resurrection' (Bowman and Malmendier, 2015; Eisdorfer, 2008), and reduce banks' performance (Zhang et al., 2016).

${ }^{2}$ Eurozone members included in our sample are Austria, Belgium, Cyprus, Estonia, Finland, France, Germany, Greece, Ireland, Italy, Latvia, Lithuania, Luxembourg, Malta, Netherlands, Portugal, Slovakia, Slovenia, and Spain. 
compute market returns, 10-year bund (German sovereign bond) yields and 10-years sovereign debt CDS from Thomson Reuters Datastream.

iii. Macroeconomic information. We obtain inflation, GDP and unemployment measurements from Eurostat.

iv. Lastly, we create an unbalanced panel of 5,160 observations for all sample quarters. All our variables are inflation-adjusted.

\section{Empirical approach}

\section{Measuring the cost of capital}

The cost of capital is defined as the return required by investors for equity investments. We follow the standard CAPM model to compute the cost of capital, which is a direct function of the safe gross rate of interest plus the compensation for bank $i$ 's undiversifiable risk. The bank's cost of capital $\left(r_{i t}\right)$ is given by:

$$
r_{i t}=R_{t}^{f}+\beta_{i t} E R P_{t}
$$

being the subscripts $i$ and $t$ the bank and the quarter, respectively. We take the 10 -year bund (German sovereign bond) yield as the risk-free rate, $R_{t}^{f}$. The variable of interest is $\beta_{\mathrm{it}}$, also known as Beta CAPM, which is calculated as the regression slope between the bank $i$ 's equity return $\left(R_{i}\right)$ and the market return portfolio $\left(R_{m}\right)$ as follows:

$$
\beta_{i t}=\frac{\operatorname{Cov}\left(R_{i}, R_{m}\right)}{\operatorname{Var}\left(R_{m}\right)}
$$

The Beta CAPM is estimated by using a 24 -month rolling-window OLS regression for each bank $i$, since betas might change significantly over time. The variable $E R P_{t}$ represents the equity market risk premium that measures the historical mean of the realized EURO STOXX returns exceeding the contemporaneous 10-year German bund yield over the past 60 months. 


\section{Identification strategy}

The identification strategy proceeds in two steps. First, we test whether NPLs have an impact on the banks' cost of capital. Second, we investigate if increases in the cost of capital lead to a reduction in lending and liquidity supply following an increase in NPLs. To this purpose, we estimate the following IV model to identify the transmission channel proposed in this article:

$$
\begin{gathered}
y_{i t}=\alpha_{0}+\alpha_{1} r_{i t-1}+X_{i t-1}^{\prime} \Theta+v_{i}+\tau_{t}+\xi_{i t} \\
r_{i t-1}=\delta_{1} N P L_{i t-2}+\delta_{2} C D S_{h t-2}+\mu_{i}+\vartheta_{t}+\varepsilon_{i t}
\end{gathered}
$$

where $y_{i t}$ is the dependent variable corresponding to the following two indicators. Firstly, we compute the lending supply $\left(L O A N T A_{i t}\right)$ as the ratio of the bank's lending volume to its total assets. Secondly, we calculate bank $i$ 's liquidity creation $\left(L C_{i t}\right)$ in thousands of euros following the three-step methodology of Berger and Bowman $(2009,2013):^{3}$

$$
\begin{array}{cc}
L C_{i t} \quad=0.5 \times \text { illiquid assets }+0.5 \times \text { liquid liabilities } \\
-0.5 \times \text { liquid assets }-0.5 \times \text { illiquid liabilities } \\
-0.5 \times \text { equity }
\end{array}
$$

As for explanatory variables, the variable of interest is the cost of capital $\left(r_{i t}\right)$ as defined in expression (1). The non-performing loans ratio $\left(N P L_{i t}\right)$ is computed as the impaired loans to total loans ratio. The variable $C D S_{h t}$ corresponds to the 10 -years sovereign CDS for the home country $(h)$ of each bank; this allows us to look into possible effects of the Eurozone's sovereign debt crisis. The matrix $X_{i t-1}^{\prime}$ is a set of control variables that includes the following one-period-lagged variables: bank's size (Size $\left.e_{i t}\right)$, measured as the natural logarithm of total assets; the leverage ratio $\left(L E V_{i t}\right)$, constructed as the bank's total assets over total equity; the income ratio $\left(I N C_{i t}\right)$, measured as non-interest income over total net income and controls for business diversification; the efficiency ratio $\left(E F F_{i t}\right)$, calculated as operating cost over gross income; and the Lerner index (Lerner ${ }_{i t}$ ), which controls for the degree of banking competition,

\footnotetext{
${ }^{3}$ Chiesa and Mansilla-Fernández $(2018,45)$ list the components of $L C_{i t}$.
} 
and is given by the ratio of the price cost margin to the price $\left(\left(P_{i t}-M C_{i t}\right) / P_{i t}\right) .{ }^{4} \mathrm{We}$ also control for macroeconomic factors: the variation rate of the Gross Domestic Product, $G D P_{h t}$, and the unemployment rate, $U N E M_{h t}$, in country $h .^{5}$

\section{Empirical findings}

The values of the estimated IV for the whole period are displayed in Table 1. In particular, Panel B of Table 1 shows the estimates of the expression (2.b). The estimates on coefficient $\delta_{1}$ are positive and significant, indicating that a one-percent increase in $N P L_{i t}$ raises the banks' cost of capital by 0.271 percent. We find that these effects are comparatively higher for banks operating in the periphery countries $(0.288)$ than for those in the core countries $(0.256)$. This result is in line with those studies that demonstrate that NPLs might reduce capital buffers and credit availability (Berger and Bowman, 2013; Dagher et al., 2014; Van der Heuvel, 2008), while increasing borrowing costs (ESRB, 2017; IMF, 2015). We add to this literature the result that the holding of NPLs increases the cost of equity financing.

The second question to be addressed in this subsection is whether the effects described above are fully transmitted to credit availability (Balgova, Nies, and Plekhanov, 2016; Bending et al., 2014). Panel A shows the results for the second-step regression. As expected, $\alpha_{1}$ estimates on the cost of capital $\left(r_{i t}\right)$ are negative and significant for lending supply $\left(L O A N T A_{i t}\right)$ and liquidity creation $\left(L C_{i t} / T A_{i t}\right)$, thus suggesting that the cost of capital acts as a transmission channel for the effects of NPLs. In line with the results presented above, we find that the impact of the cost of capital on lending and liquidity supply is comparatively more significant for periphery country banks than for core country banks. Importantly, the estimates on the

${ }^{4}$ Carbó-Valverde, Mansilla-Fernández, and Rodríguez-Fernández (2017) demonstrate that the degree of competition is a determinant of the lending supply. 
interaction variable $\left(r_{i t-1} \times L E V_{i t-1}\right)$ suggest that the less capitalized the bank is, the greater the negative effects of the cost of capital are on lending and liquidity creation. This complements the results by Ghosh (2006) and Petersen et al. (2010) who show that leverage (capital scarcity) fosters NPLs.

The standard Sargan's test rejects the null and demonstrates the orthogonality of the instruments used in this study. Lastly, valid inference is ensured since standard error and test statistics are robust to heteroscedasticity and clustering at the specialization level.

As a robustness test, Table 2 introduces the 10-years sovereign $\operatorname{CDS}\left(C D S_{h t}\right)$ for the period 2008Q1-2016Q4 to test if our results on expression (2.b) might be driven by the sovereign debt crisis (Louzis, Vouldis, and Metaxas, 2012; Pinto and Picoto, 2018). The estimates on $\delta_{2}$ are positive and significant, thus suggesting that the sovereign debt crisis contributed to increasing the cost of capital. Furthermore, periphery country banks were comparatively more exposed to CDS than core country banks.

\section{Conclusions}

We have examined the effects of NPLs on lending and liquidity supply, as a result of the increase in the bank cost of capital induced by NPL holdings. As predicted by previous literature on banking regulation (Berger and Bowman, 2013; Dagher et al., 2014; van der Heuvel, 2008), banks should maintain sufficiently high levels of capital to provide credit to customers. The bank's cost of capital will then affect bank lending.

Specifically, we have shown that banks holding a certain volume of NPLs are perceived as relatively risky by equity investors, who then require higher equity returns as a compensation for bearing undiversifiable risk. As a result, the higher the volume of NPLs held by a bank, the higher its cost of capital. Secondly, in line with previous studies showing that NPLs increase banks' borrowing costs and adversely affect lending (ESRB, 2017; IMF, 2015), we demonstrate that banks facing a more expensive cost of equity reduce risk-taking by limiting 
lending and liquidity creation. Importantly, these effects are exacerbated by the shortage of bank capital.

To the best of our knowledge, this is one of the first articles that investigates the impact of the NPLs ratio on banks' cost of capital, and the effect on lending and liquidity supply as a unique transmission channel. Results are robust to the endogeneity tests. However, since information about 10-year sovereign CDS is available from 2008 onwards, the analysis of their impact on the cost capital has been limited to the crisis period. An interesting question left for future research concerns the effects of management of NPLs and the possible implications resulting from State guarantees. 
Table 1. Regression results (2002Q1 - 2016Q4)

\begin{tabular}{|c|c|c|c|c|c|c|}
\hline & \multicolumn{3}{|c|}{ LOANTA $_{\text {it }}$} & \multicolumn{3}{|c|}{$L C_{i t} / T A_{i t}$} \\
\hline & Eurozone & $\begin{array}{l}\text { Periphery } \\
\text { Countries }\end{array}$ & $\begin{array}{c}\text { Core } \\
\text { Countries }\end{array}$ & Eurozone & $\begin{array}{l}\text { Periphery } \\
\text { Countries }\end{array}$ & $\begin{array}{c}\text { Core } \\
\text { Countries } \\
\end{array}$ \\
\hline & $(1)$ & $(2)$ & (3) & (4) & $(5)$ & $(6)$ \\
\hline \multicolumn{7}{|c|}{ Panel A: Second step regression } \\
\hline$r_{i t-1}$ & $-0.089^{* * * *}$ & $-0.091^{* * *}$ & $-0.073^{* * *}$ & $-0.077^{* * * * *}$ & $-0.082^{* * * *}$ & - \\
\hline & $(0.014)$ & $(0.012)$ & $(0.012)$ & $(0.014)$ & $(0.016)$ & $\begin{array}{c}0.073 \\
(0.016)\end{array}$ \\
\hline$L E V_{i t-1}$ & $\begin{array}{c}-0.116^{* * * *} \\
(0.034)\end{array}$ & $\begin{array}{c}-0.126^{* * * *} \\
(0.025)\end{array}$ & $\begin{array}{c}-0.085^{\text {**** }} \\
(0.023)\end{array}$ & $\begin{array}{c}-0.112^{* * *} \\
(0.034)\end{array}$ & $\begin{array}{c}-0.143^{* * * *} \\
(0.040)\end{array}$ & $\begin{array}{c}-0.093^{* * * *} \\
(0.032)\end{array}$ \\
\hline $\begin{array}{l}r_{i t-1} \times \\
L E V_{i t-1}\end{array}$ & $-0.172^{* * *}$ & $-0.184^{* * *}$ & $-0.163^{* * *}$ & $-0.243^{* * *}$ & $-0.264^{* * *}$ & $-0.214^{* * *}$ \\
\hline & $(0.024)$ & $(0.026)$ & $(0.023)$ & $(0.061)$ & $(0.064)$ & $(0.056)$ \\
\hline Crisist & $\begin{array}{c}-0.048^{* * * *} \\
(0.009)\end{array}$ & $\begin{array}{c}-0.055^{* *} \\
(0.011)\end{array}$ & $\begin{array}{c}-0.035^{* * *} \\
(0.007)\end{array}$ & $\begin{array}{l}0.043^{* * *} \\
(0.008)\end{array}$ & $\begin{array}{l}0.046^{* * * *} \\
(0.011)\end{array}$ & $\begin{array}{c}0.037^{* * * *} \\
(0.007)\end{array}$ \\
\hline \multicolumn{7}{|c|}{ Panel B: First step regression } \\
\hline$N P L_{i t-2}$ & $\begin{array}{c}0.271^{* * *} \\
(0.049)\end{array}$ & $\begin{array}{c}0.288^{* * * *} \\
(0.048)\end{array}$ & $\begin{array}{c}0.256^{* * *} \\
(0.046)\end{array}$ & $\begin{array}{c}0.271^{* * *} \\
(0.049)\end{array}$ & $\begin{array}{c}0.288^{* * *} \\
(0.048)\end{array}$ & $\begin{array}{c}0.256^{* * *} \\
(0.046)\end{array}$ \\
\hline$X_{i t-1}^{\prime}$ & Yes & Yes & Yes & Yes & Yes & Yes \\
\hline $\begin{array}{l}\text { Bank } \\
\text { FE }\end{array}$ & Yes & Yes & Yes & Yes & Yes & Yes \\
\hline $\begin{array}{l}\text { Time } \\
\text { FE }\end{array}$ & Yes & Yes & Yes & Yes & Yes & Yes \\
\hline$N$ & 4,988 & 3,016 & 1,972 & 4,988 & 3,016 & 1,972 \\
\hline $\begin{array}{l}\text { Sargan } \\
\text { test [ } p \text { - } \\
\text { value] }\end{array}$ & 0.1383 & 0.1502 & 0.1247 & 0.1482 & 0.1694 & 0.1357 \\
\hline $\begin{array}{l}\text { Wald's } \\
\text { test [ } p \text { - } \\
\text { value] }\end{array}$ & 0.0000 & 0.0000 & 0.0000 & 0.0000 & 0.0000 & 0.0000 \\
\hline
\end{tabular}

Notes: $*, * *, * * *$ are statistically significant at the 10,5 and $1 \%$ level, respectively.

Source: Own elaboration. 
Table 2. Regression results (2008Q1 - 2016Q4)

\begin{tabular}{|c|c|c|c|c|c|c|}
\hline & \multicolumn{3}{|c|}{ LOANTA $_{\text {it }}$} & \multicolumn{3}{|c|}{$L C_{i t} / T A_{i t}$} \\
\hline & Eurozone & $\begin{array}{l}\text { Periphery } \\
\text { Countries }\end{array}$ & $\begin{array}{c}\text { Core } \\
\text { Countries }\end{array}$ & Eurozone & $\begin{array}{l}\text { Periphery } \\
\text { Countries }\end{array}$ & $\begin{array}{c}\text { Core } \\
\text { Countries } \\
\end{array}$ \\
\hline & $(1)$ & (2) & $(3)$ & (4) & $(5)$ & $(6)$ \\
\hline \multicolumn{7}{|c|}{ Panel A: Second step regression } \\
\hline$r_{i t-1}$ & $\begin{array}{c}-0.082^{* * * *} \\
(0.013)\end{array}$ & $\begin{array}{c}-0.085^{* * *} \\
(0.014)\end{array}$ & $\begin{array}{c}-0.073^{* * * *} \\
(0.012)\end{array}$ & $\begin{array}{c}-0.089^{* * * *} \\
(0.019)\end{array}$ & $\begin{array}{c}-0.094^{* * * *} \\
(0.021)\end{array}$ & $\begin{array}{c}-0.083^{* * * *} \\
(0.019)\end{array}$ \\
\hline$L E V_{i t-1}$ & $\begin{array}{c}-0.117^{* * * *} \\
(0.016)\end{array}$ & $\begin{array}{c}-0.123^{* * *} \\
(0.019)\end{array}$ & $\begin{array}{c}-0.105^{* * *} \\
(0.014)\end{array}$ & $\begin{array}{c}-0.122^{* * *} \\
(0.021)\end{array}$ & $\begin{array}{c}-0.129^{* * *} \\
(0.025)\end{array}$ & $\begin{array}{c}-0.117^{* * * *} \\
(0.020)\end{array}$ \\
\hline $\begin{array}{l}r_{i t-1} \times \\
L E V_{i t-1}\end{array}$ & $\begin{array}{c}-0.165^{\text {**** }} \\
(0.021)\end{array}$ & $\begin{array}{c}-0.175^{* * *} \\
(0.023)\end{array}$ & $\begin{array}{c}-0.157^{* * * *} \\
(0.018)\end{array}$ & $\begin{array}{c}-0.136^{* * *} \\
(0.023)\end{array}$ & $\begin{array}{c}-0.144^{* * *} \\
(0.024)\end{array}$ & $\begin{array}{c}-0.131^{\text {**** }} \\
(0.021)\end{array}$ \\
\hline \multicolumn{7}{|c|}{ Panel B: First step regression } \\
\hline$N P L_{i t-2}$ & $\begin{array}{c}0.125^{* * *} \\
(0.025)\end{array}$ & $\begin{array}{c}0.127^{* * *} \\
(0.032)\end{array}$ & $\begin{array}{c}0.122^{* * * *} \\
(0.023)\end{array}$ & $\begin{array}{c}0.125^{* * *} \\
(0.025)\end{array}$ & $\begin{array}{c}0.127^{* * * *} \\
(0.032)\end{array}$ & $\begin{array}{c}0.122^{* * *} \\
(0.023)\end{array}$ \\
\hline$C D S_{h t-2}$ & $\begin{array}{c}0.002^{* * * *} \\
(0.000)\end{array}$ & $\begin{array}{l}0.003^{* * *} \\
(0.0001)\end{array}$ & $\begin{array}{c}0.002^{* * * *} \\
(0.000)\end{array}$ & $\begin{array}{c}0.002^{* * * *} \\
(0.000)\end{array}$ & $\begin{array}{l}0.003^{* * * *} \\
(0.0001)\end{array}$ & $\begin{array}{c}0.002^{* * * *} \\
(0.000)\end{array}$ \\
\hline$X_{i t-1}^{\prime}$ & Yes & Yes & Yes & Yes & Yes & Yes \\
\hline $\begin{array}{l}\text { Bank } \\
F E\end{array}$ & Yes & Yes & Yes & Yes & Yes & Yes \\
\hline $\begin{array}{l}\text { Time } \\
\text { FE }\end{array}$ & Yes & Yes & Yes & Yes & Yes & Yes \\
\hline$N$ & 3,096 & 1,872 & 1,224 & 3,096 & 1,872 & 1,224 \\
\hline $\begin{array}{l}\text { Sargan } \\
\text { test }[p- \\
\text { value }]\end{array}$ & 0.1355 & 0.1485 & 0.1264 & 0.1472 & 0.1573 & 0.1367 \\
\hline $\begin{array}{l}\text { Wald's } \\
\text { test }[p- \\
\text { value] }\end{array}$ & 0.0000 & 0.0000 & 0.0000 & 0.0000 & 0.0000 & 0.0000 \\
\hline
\end{tabular}

Notes: $*, * *, * * *$ are statistically significant at the 10,5 and $1 \%$ level, respectively.

Source: Own elaboration. 
References

Accornero, M., P. Alessandri, L. Carpinelli, and A.M. Sorrentino. 2017. "Non-Performing Loans and the Supply of Bank Credit: Evidence from Italy". Bank of Italy Occasional Paper No. 374. Available at SSRN: https://ssrn.com/abstract=2954995 or http://dx.doi.org/10.2139/ssrn.2954995

Afonso, G, A. Kovener, and A. Schoarn. 2011. "Stressed, not frozen: The Federal Funds market in the financial crisis”. Journal of Finance 66: 1109-1139. doi: https://doi.org/10.1111/j.1540-6261.2011.01670.x

Aiyar, S., W. Bergthaler, J.M. Garrido, A. Ilyna, A. Jobst, K. Kang, D. Kovtun, D. Monaghan, and M. Moretti. 2015. “A strategy for resolving Europe's problem loans”. IMF Staff Discussion Note. Available at: https://www.imf.org/external/pubs/ft/sdn/2015/sdn1519.pdf Balgova, M., M. Nies, and A. Plekhanov. 2016. "The economic impact of reducing nonperforming loans”. EBRD Working Paper No. 193, European Bank for Reconstruction and Development, London. Available at: http://npl.vienna-initiative.com/wpcontent/uploads/sites/2/2017/02/EBRD-The-Economic-Impact-of-Reducing-NPLs$\underline{\text { WP_193.pdf }}$

Bending, T., M. Berndt, P. Brutscher, O. Nelvin, D. Revoltella, T. Slacik, and M. Wolski. 2014. "Unlocking lending in Europe. European Investment Bank". European Investment Bank. Available at: http://www.eib.org/infocentre/publications/all/unlocking-lending-ineurope.htm

Berger, A.N., and C.H.S. Bouwman. 2009. "Bank liquidity creation". Review of. Financial Studies 22: 3779-3837. doi: https://doi.org/10.1093/rfs/hhn104 
Berger, A.N., and C.H.S. Bouwman. 2013. "How does capital affect bank performance during financial crises?" Journal of Financial Economics 109: 146-176. doi:

https://doi.org/10.1016/j.jfineco.2013.02.008

Berger, A. N., and R. DeYoung. 1997. "Problem Loans and Cost Efficiency in Commercial Banks". Journal of Banking and Finance 21: 849-870. doi: https://doi.org/10.1016/S0378$\underline{4266(97) 00003-4}$

Bowman, C.H.S., and U. Malmendier. 2015. "Does a bank's history affect its risk taking?" American Economic Review 105: 321-325. doi: 10.1257/aer.p20151093

Calomiris, C.W., and M. Jaremski. 2016. "Deposit insurance: Theories and facts". NBER Working Papers Series 22223. Available at: http://www.nber.org/papers/w22223.pdf

Caprio, G., and L.H. Summers. 1993. "Finance and its reform: Beyond laissez-faire”. Policy Research Working Paper No. 1993/08/31 WPS1171.

Carbó-Valverde, S., J.M. Mansilla-Fernández, and F. Rodríguez-Fernández. 2017. “The effects of bank market power in the short-term and the long-term firm credit availability and investment”. Spanish Journal of Finance and Accounting 46: 1-27. doi: https://doi.org/10.1080/02102412.2016.1242239

Chiesa, G., and J.M. Mansilla-Fernandez. 2018. "Non-performing loans, cost of capital, and lending supply: Lessons from the Eurozone banking crisis". Departmental Working Papers 2018-05, Department of Economics, Management and Quantitative Methods at Università degli Studi di Milano. Available at SSRN: https://ssrn.com/abstract=3195767 
Dagher, J., G. Dell'Ariccia, L. Laeven, L. Ratnovski, and H. Tong. 2014. "Benefits and Costs of Bank Capital". IMF Staff Discussion Note, 16/04. Available at:

https://www.imf.org/external/pubs/ft/sdn/2016/sdn1604.pdf

Eisdorfer, A. 2008. "Empirical evidence of risk shifting in financially distressed banks". Journal of Finance 63: 609-637. Doi: https://doi.org/10.1111/j.1540-6261.2008.01326.x

European Systemic Risk Board (ESBR). 2017. Resolving non-performing loans in Europe. July 2017. Available at:

https://www.esrb.europa.eu/pub/pdf/reports/20170711_resolving_npl_report.en.pdf

Ghosh, S. 2006. "Does leverage influence banks' non-performing loans? Evidence from India”. Applied Economics Letters 12: 913-918. doi:

https://doi.org/10.1080/13504850500378064

International Monetary Fund (IMF). 2015. "Euro area policies, selected issues: policy options for tackling non-performing loans in the euro area." Available at https://www.imf.org/external/pubs/ft/scr/2015/cr15205.pdf

Louzis, D.P., A.T. Vouldis, and V.L. Metaxas. 2012. "Macroeconomic and bank-specific determinants of non-performing loans in Greece: A comparative study of mortgage, business and consumer loan portfolios". Journal of Banking and Finance 36: 1012-1027. doi: https://doi.org/10.1016/j.jbankfin.2011.10.012

Petersen, M.A., M. P. Mulaudzi, J. Mukuddem-Petersen, and I. Schoeman. 2010. “A note on the subprime mortgage crisis: dynamic modelling of bank leverage profit under loan securitization". Applied Economics Letters 17: 1469-1474. doi: https://doi.org/10.1080/13504850903035907 
Pinto, I., and W.N. Picoto. 2018. "Earnings and capital management in European banks Combining a multivariate regression with a qualitative comparative analysis". Journal of Business Research 89: 258-264. doi: https://doi.org/10.1016/j.jbusres.2017.12.034

Van den Heuvel, S.J. 2008. "The welfare cost of bank capital requirements". Journal of Monetary Economics 55: 298-320. doi: https://doi.org/10.1016/j.jmoneco.2007.12.001

Zhang, D., J. Cai, D.G. Dickinson, and A.M. Kutan. 2016. "Non-performing loans, moral hazard and regulation of the Chinese commercial banking system”. Journal of Banking and Finance 63: 48-60. doi: https://doi.org/10.1016/j.jbankfin.2015.11.010 